\title{
基于低温化学气相沉积法的碳化硅纤维表面氮化硓涂层 制备及表征
}

\author{
王驰，孙妮娟" , 张娟，张大海 \\ 航天材料及工艺研究所, 先进功能复合材料技术国防科技重点实验室, 北京 100076 \\ * 联系人, E-mail: sunnijuan@pku.org.cn
}

2016-04-05 收稿, 2016-05-06 修回, 2016-05-06 接受, 2016-07-14 网络版发表

国家高技术研究发展计划(2014AA7024034)资助

\begin{abstract}
摘要以硼氨烷络合物为前驱体, 采用低温化学气相沉积 $(C V D)$ 工艺, 在碳化硅纤维表面制备了氮化嗍 $(B N)$ 涂 层. 采用扫描电子显微镜(SEM)、俄歇电子能谱(AES)、傅里叶变换红外光谱(FTIR)和掠入射X射线衍射(GIAXRD) 对涂层进行了表征, 采用单纤维电子强力仪测试了碳化硅纤维沉积BN涂层前后的拉伸强度. 结果表明BN涂层无 孔洞裂纹等缺陷, 且表面均一致密, $\mathrm{B}, \mathrm{N}$ 元素比例接近为 $1: 1$, 纤维与涂层之间相互渗透, 结合良好. 在较低的沉 积温度下可以得到成分单一的BN涂层, 涂层微观结构随温度升高更加理想. 综合考虑结晶性与纤维强度保留率 的情况下, $800 \sim 1000^{\circ} \mathrm{C}$ 可作为碳化硅纤维 $\mathrm{BN}$ 涂层的最佳沉积温度。在沉积温度为 $900^{\circ} \mathrm{C}$ 时, 随涂层厚度的增加至 $0.28,0.51$ 和 $0.82 \mu \mathrm{m}$, 纤维强度保留率分别为 $92.7 \%, 83.6 \%, 77.7 \%$.
\end{abstract}

关键词嗍氨烷络合物, 化学气相沉积, 碳化硅纤维, BN 涂层

氮化嗍(BN)以其优异的性能, 如高热稳定性、化 学稳定性、热传导率、抗热震性和低介电常数被认为 是非常有希望的陶瓷材料之一. 氮化嗍纤维、薄膜、 块体可以广泛地应用在电子设备、微波器件、透波材 料、摩擦材料和航空航天领域 ${ }^{[1 ~ 5]}$.

六方氮化硼 $(h-\mathrm{BN})$ 有着类石墨的层状堆积结构, 每一层面内由嗍和氮交替强共价键连接形成六边形 结构, 层间由范德华力作用 ${ }^{[6,7]}$. 在陶瓷基复合材料 中, 六方氮化嗍因其更好的抗氧化性能(氮化嗍在空 气中的起始氧化温度为 $800^{\circ} \mathrm{C}$, 而热解碳为 $450^{\circ} \mathrm{C}$ ), 可以替代热解碳作为陶瓷基复合材料纤维和基体之 间的界面涂层. 另外, 氮化嗍氧化后形成的 $\mathrm{B}_{2} \mathrm{O}_{3}$ 可 以愈合微裂纹, 阻止氧化性气氛的扩散 ${ }^{[8 \sim 10]}$.

化学气相沉积法 $(C V D)$ 是目前国内外制备氮化 硼涂层最常用的方法 ${ }^{[11]}$. 化学气相沉积法设备简单,
维护方便，灵活性强，可通过对反应室尺寸和反应气 体驻留时间的调节在纳米到微米级别来控制涂层厚 度, 并且涂层致密、均匀, 同时也可以较好地控制涂 层的密度、纯度和晶粒度. 通常, 根据硼和氮来源的 不同, 化学气相沉积可以分为双组元和单组元两种体 系. 其中, 硼源和氮源为不同物质时为双组元体系, 如最常用的 $\mathrm{BCl}_{3}-\mathrm{NH}_{3}-\mathrm{Ar}-\mathrm{H}_{2}, \mathrm{BF}_{3}-\mathrm{NH}_{3}-\mathrm{Ar}-\mathrm{H}_{2}$ 体系 ${ }^{[12,13]}$, 其中 $\mathrm{BCl}_{3}, \mathrm{BF}_{3}$ 为嗍源, $\mathrm{NH}_{3}$ 为氮源, $\mathrm{Ar}, \mathrm{H}_{2}$ 作为载气和 稀释气体. 然而, 双组元体系中生成的副产物如 $\mathrm{HCl}$, $\mathrm{HF}$ 等气体具有腐蚀性，且不易形成化学计量比的 BN 涂层，生成的 $\mathrm{NH}_{4} \mathrm{Cl}$ 也会造成管路的堵塞. 此外，双 组元前驱体制备 $\mathrm{BN}$ 时沉积温度大都集中在 $1000^{\circ} \mathrm{C}$ 以 上, 制备过程对纤维的强度损伤较大. 另一种为单组 元前驱体，前驱体同时含有硼源和氮源，如硼呋嗪 $\left(\mathrm{B}_{3} \mathrm{~N}_{3} \mathrm{H}_{6}\right)^{[14]}$ 、三氯嗍呋嗪 $\left(\mathrm{B}_{3} \mathrm{~N}_{3} \mathrm{H}_{3} \mathrm{Cl}_{3}\right)^{[15]}$ 等, 嗍与氮的

引用格式: 王驰, 孙妮娟, 张娟, 等. 基于低温化学气相沉积法的碳化硅纤维表面氮化硼涂层制备及表征. 科学通报, 2016, 61: 2536-2542 Wang C, Sun N J, Zhang J, et al. Preparation and characterization of boron nitride coating on silicon carbide fibers based on low-temperature chemical vapor deposition (in Chinese). Chin Sci Bull, 2016, 61: 2536-2542, doi: 10.1360/N972016-00451 
比例为 $1: 1$, 易于形成化学计量比的氮化嗍. 但嗍呋 嗪化学性能不稳定, 而且三氯硼呋嗪作为前驱体时 会产生腐蚀性气体.

单组元前驱体硼氨烷络合物 $\left(\mathrm{BH}_{3} \mathrm{NH}_{3}\right)$ 同时含有 $\mathrm{B}, \mathrm{N}$ 两种元素, 无毒无污染、不易燃、不易爆, 室温

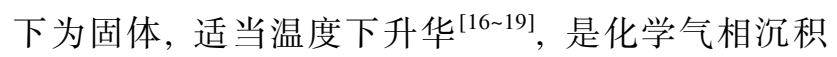
法制备氮化嗍优秀的备选前驱体之一, 制备的BN可 以作为陶瓷基复合材料的界面涂层. 而碳化硅纤维 增强陶瓷基复合材料, 特别是 $\mathrm{SiC} / \mathrm{SiC}$ 复合材料在航 空航天、新能源等方面有广阔的应用前景. 碳化硅纤 维与基体之间的BN界面涂层可以起到传递载荷、偏 折裂纹、使纤维拔出等作用增强复合材料韧性. 相比 于双组元前驱体, 以硼氨烷络合物为前驱体制备的 $\mathrm{BN}$ 涂层在较低温度下具有良好的结晶性能, 可最大 限度地减少制备过程中高温对碳化硅纤维力学性能 的影响. 本文通过低温化学气相沉积, 以硼氨烷络合 物为单组元前驱体, 在碳化硅纤维表面制备了氮化 硼涂层, 对涂层的形貌、元素组成、微观结构进行了 表征, 并研究了以此方法制备的氮化嗍涂层对碳化 硅纤维力学性能的影响.

\section{1 实验}

(i ) 原料. 嗍氨烷络合物 $\left(\mathrm{BH}_{3} \mathrm{NH}_{3}, 98.2 \%\right)$ 来 自北京伊诺凯科技有限公司; 碳化硅纤维为江苏赛 力菲公司生产的SLF-SiC-NF-10纤维, 拉伸强度 $2.2 \pm$ $0.4 \mathrm{GPa}$, 直径 $14 \pm 2 \mu \mathrm{m}, 1000$ 根/束.

(ii) 实验过程. 本实验采用热壁化学气相沉积 管式炉进行氮化嗍纤维涂层的制备. 碳化硅纤维在 丙酮中超声浸渍 $30 \mathrm{~min}$, 除去表面保护胶, 然后放人 烘箱中, 温度 $100^{\circ} \mathrm{C}, 2 \mathrm{~h}$ 烘干. 除胶后的碳化硅纤维 放置在管式炉的石英管反应区中, 反应装置如图 1所 示. 前驱体嗍氨烷络合物 $\left(\mathrm{BH}_{3} \mathrm{NH}_{3}\right)$ 放置在反应室左 侧石英管内的石英舟上, 与反应室形成一个封闭体 系. 反应期间, 加热带加热至 $110 \sim 130^{\circ} \mathrm{C}$ 使前驱体升 华, 由 $\mathrm{Ar}$ 气作为载气运送升华后的前驱体至反应区 沉积, 载气流量100 300 sccm. 由于前驱体的升华是 一个快速的过程, 普通的一次性加热不能保证长时 间的沉积. 为了使沉积能持续的进行, 本实验将前驱 体按一定长度均匀平铺在石英舟上, 在反应进行的 过程中, 加热带以 $0.167 \mathrm{~cm} / \mathrm{min}$ 的速率向右运动, 使 前驱体能够持续供应. 同时, $\mathrm{Si} / \mathrm{SiO}_{2}$ 片也作为沉积的 基底, 可以用来测试傅里叶变换红外光谱(FTIR,

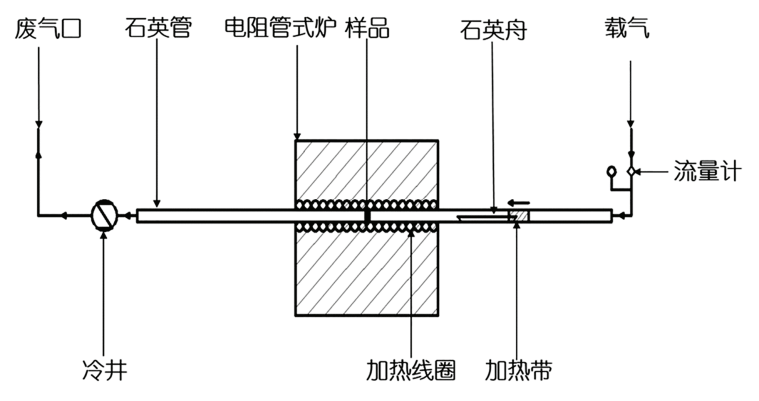

图 1 低温CVD制备BN涂层反应装置示意图

Figure 1 Schematic diagram for preparation of BN coatings by CVD

V70FTIR，Bruker) 和掠人射 X 射线衍射 (GIAXRD, D/Max 2500v, Rigaku).

(iii) 性能测试. 扫描电子显微镜 (SEM, SU8010, Hitachi)用来表征纤维涂层表面和横截面形貌. 俄歇电子能谱(AES, PHI-700, ULVAC-PHI), 扫描型 $\mathrm{Ar}^{+}$枪深度溅射, 溅射速率49 $\mathrm{nm} / \mathrm{min}$. 测试元素组成 以及在深度方向上各元素的相对百分含量. 用FTIR 来测试涂层的化学成分, 测试范围4000 600 $\mathrm{cm}^{-1}$. GIAXRD用来测试涂层的相组成和结晶性能, 人射 角为 $1^{\circ}$, 扫描速度 $3 \% \mathrm{~min}$. GIAXRD 人射角较小, 如本 实验固定为 $1^{\circ}$, 信号探测器做 $2 \theta$ 角转动. 相比于普 通 XRD 人射 X射线和信号探测器同时做 $\theta$ 角转动, GIAXRD的固定角只人射至材料表面, 没有深人材 料内部, 对材料表面和界面结构信息敏感, 可以测量 较薄的涂层, 消除基底的影响; 所以在 $\mathrm{Si} / \mathrm{SiO}_{2}$ 片上 沉积BN涂层, 进行FTIR和GIAXRD的表征. 纤维强 度由单纤维电子强力仪(YG001, 太仓纺织厂)表征, 加载速率 $1.5 \mathrm{~mm} / \mathrm{s}$.

\section{2 结果与讨论}

\section{1 碳化硅纤维表面涂层微观形貌分析}

图 2 为 $900^{\circ} \mathrm{C}$ 下碳化硅纤维沉积 $\mathrm{BN}$ 涂层前后的横 截面与SEM形貌图. 图2(a)和(b)分别为空白碳化硅 纤维和沉积有 $\mathrm{BN}$ 涂层的碳化硅纤维横截面形貌, 可 以看出, $\mathrm{BN}$ 涂层连续紧密地包裹在碳化硅纤维外层, 涂层厚度为 $0.51 \mu \mathrm{m}$, 没有出现孔洞和裂纹等缺陷, 与纤维的结合良好. 图2(c) (f) 为空白纤维和沉积 BN 涂层后的表面形貌，其中图2(c)和(e)为空白碳化硅纤 维的表面形貌, 空白碳化硅纤维表面光滑均匀, 无沟 道等缺陷. 图 2(d)和(f)为 $900^{\circ} \mathrm{C}$ 下碳化硅纤维沉积 $\mathrm{BN}$ 涂层后的表面形貌, 涂层均一致密, 无颗粒聚集、裂 


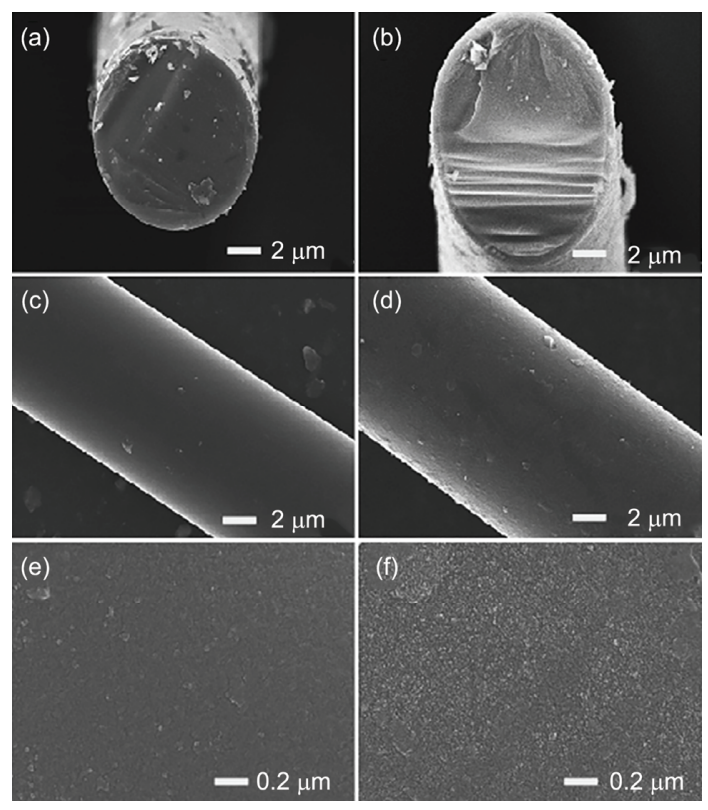

图 2 沉积温度为 $900^{\circ} \mathrm{C}$ 时得到的沉积 $\mathrm{BN}$ 涂层前后的碳化硅纤维横截 面和表面SEM对比形貌图. 空白(a)和沉积(b)BN涂层后的碳化硅纤 维横截面; (c), (e) 空白碳化硅纤维表面; (d), (f) 沉积BN涂层后的碳 化硅纤维表面

Figure 2 Cross-section and surface morphology of BN coated silicon carbide fibers deposited at $900^{\circ} \mathrm{C}$ and bare silicon carbide fibers by SEM. Cross-section morphology SEM images of bare fiber (a) and BN coated fiber at $900^{\circ} \mathrm{C}$ (b). (c), (e) Surface morphology of bare fiber; (d), (f) surface morphology of $\mathrm{BN}$ coated fiber at $900^{\circ} \mathrm{C}$

纹等缺陷, 涂层连续地包覆在碳化硅纤维上, 晶粒细 小, 平均粒径在10 25 $\mathrm{nm}$ 之间. 结果表明, 此方法可 以在碳化硅纤维表面制备均匀连续致密、可获得应用 的涂层. 涂层的厚度与沉积温度、时间有关, 而在一 定温度下, 可通过调节沉积时间实现对涂层厚度的 精细化控制.

\section{2 碳化硅纤维表面涂层成分分析}

采用俄歇电子能谱表征涂层沿厚度方向的元素 组成, 对涂层的化学成分进行确认. 图 3 为 $900^{\circ} \mathrm{C}$ 下碳 化硅纤维表面涂层的AES图谱, 对 B, N, C, O, Si 5种 元素进行深度溅射分析. 从俄歇电子能谱可以看出, 涂层的主要元素为 $\mathrm{B}, \mathrm{N}$, 且比例接近 $1: 1, \mathrm{Si}, \mathrm{C}, \mathrm{O}$ 的 含量极少, 说明碳化硅纤维表面涂层的主要成分为 BN. 从图 3 中也可以看出 $\mathrm{N}$ 元素含量相比于 B元素略 低, 这是由于 $\mathrm{Ar}^{+}$离子轰击 $\mathrm{BN}$ 时, $\mathrm{N}$ 元素会被优先溅 射所导致 ${ }^{[4]}$. 随着溅射深度的增加, $\mathrm{B}, \mathrm{N}$ 两种元素仍 保持近似为 $1: 1$ 的比例, 说明在该沉积过程中能够获 得组分较为单一的BN涂层. 溅射深度超过 $0.28 \mu \mathrm{m}$ 后,

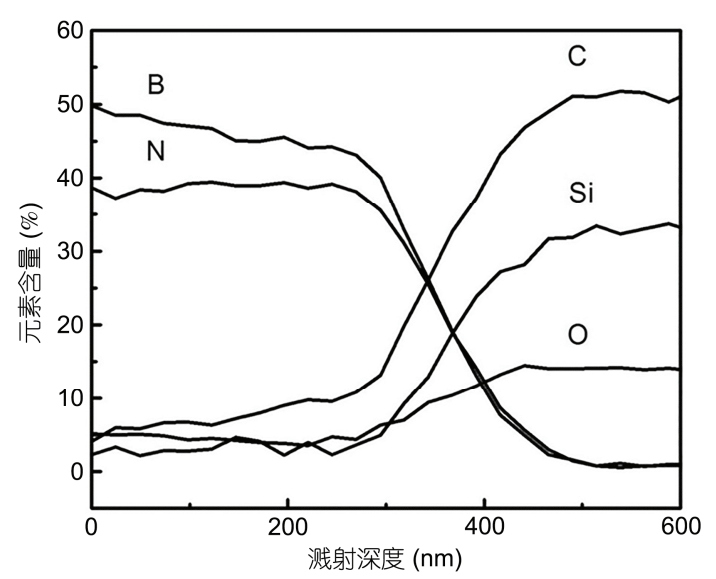

图 3 碳化硅纤维表面BN涂层深度剖析俄歇电子能谱

Figure 3 AES depth profile of CVD BN-coated silicon carbide fibers

$\mathrm{Si}, \mathrm{C}, \mathrm{O}$ 含量逐渐上升, B, N含量逐渐下降至接近于零, 说明纤维/涂层之间相互渗透, 涂层与纤维结合良好.

$\mathrm{AES}$ 的表征结果表明在碳化硅纤维表面成功地 沉积制备了BN涂层, 并且在纤维/涂层界面处二者相 互渗透, 结合良好. 在陶瓷基复合材料中, 涂层与纤 维良好的结合可以保证作为界面的涂层使产生于基 体的裂纹在界面涂层之间偏转，增强复合材料㓞性.

\section{3 碳化硅纤维表面涂层微观结构表征}

为了获得不同温度下在 $\mathrm{Si} / \mathrm{SiO}_{2}$ 片上沉积得到的 $\mathrm{BN}$ 涂层的微观结构, 采用FTIR法对涂层进行表征. 图4为不同沉积温度下 $\mathrm{BN}$ 涂层的FTIR 图谱, 沉积温 度分别为 800,900 和 $1000^{\circ} \mathrm{C}$, 同时对嗍氨烷络合物进 行了FTIR对比分析.

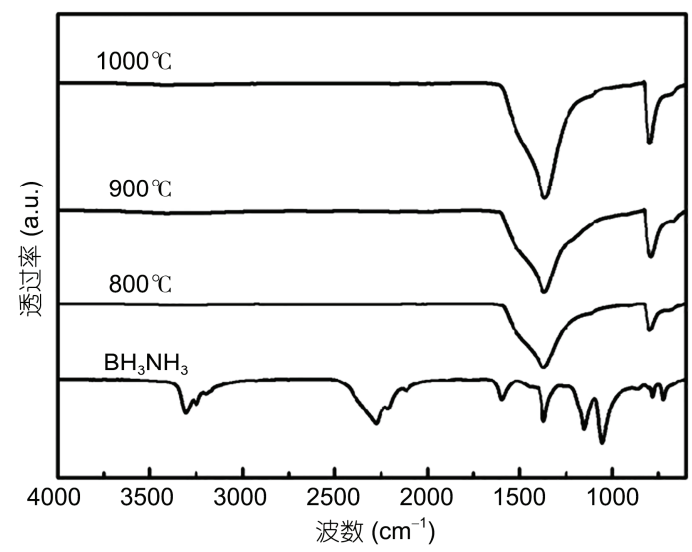

图 $4800 \sim 1000^{\circ} \mathrm{C}$ 沉积的BN涂层和嗍氨烷络合物的FTIR光谱图

Figure 4 FTIR spectra of the coatings deposited at $800-1000^{\circ} \mathrm{C}$ respectively, compared with ammonia borane 
硼氨烷络合物的典型吸收谱可以在 4000 600 $\mathrm{cm}^{-1}$ 很宽的范围内检测到. 其中, 波数在 3305,3248 $3195 \mathrm{~cm}^{-1}$ 处的吸收峰由 $\mathrm{N}-\mathrm{H}$ 的的伸缩振动引起, 而 波数在 $1597,1369,1053 \mathrm{~cm}^{-1}$ 处的吸收峰为 $\mathrm{N}-\mathrm{H}$ 的面 内弯曲振动. B-H的伸缩振动峰在 $2277,2214,2115$ $\mathrm{cm}^{-1}$ 波数处, 面内弯曲振动峰在 $1153,723 \mathrm{~cm}^{-1}$ 两处 可检测到. $779 \mathrm{~cm}^{-1}$ 处的吸收峰为 $\mathrm{B}-\mathrm{N}$ 的伸缩振动. 这些检测结果与文献 $[20,21]$ 报道的结果相符合. 前 驱体嗍氨烷络合物同时存在着B-N, B-H, N-H 3种化 学键的吸收峰.

对于上述温度下沉积的涂层, 在 1371 和 $795 \mathrm{~cm}^{-1}$ 都出现了两处明显的吸收峰, 其中 $1371 \mathrm{~cm}^{-1}$ 处为 B-N键的伸缩振动, 波数为 $795 \mathrm{~cm}^{-1}$ 的吸收峰是 $\mathrm{B}-\mathrm{N}$ 键的面内弯曲振动 ${ }^{[22]}$. 在 $800 \sim 1000^{\circ} \mathrm{C}$ 的温度范围内, 沉积得到了 $\mathrm{BN}$ 涂层, 且并未观察到 $\mathrm{B}-\mathrm{H}, \mathrm{N}-\mathrm{H}$ 的伸缩 和弯曲振动所引起的吸收峰, 说明沉积过程中前驱 体分解得较完全.

为进一步证明碳化硅纤维表面BN涂层的微观结 构, 对不同温度下在 $\mathrm{Si} / \mathrm{SiO}_{2}$ 片上沉积的 $\mathrm{BN}$ 涂层进行 GIAXRD表征, 获得了涂层的精细结构和晶型的详 细信息. 图5给出了沉积温度在 $800 \sim 1000^{\circ} \mathrm{C}$ 范围内所 制备BN涂层的GIAXRD图谱. 从图中可以看出, 在 上述温度下, 涂层均有两个主要的衍射峰, 分别在 $24^{\circ}$ 和 $42^{\circ}$ 左右, $24^{\circ}$ 左右的衍射峰对应六方氮化嗍 (002)面的衍射, 而 $42 \circ$ 左右的衍射峰为 (100)和(101) 两个晶面衍射的叠加. 结合 (002)面比较宽的衍射峰 $\left(d_{(002)}\right.$ 间距较大 $)$ 和FTIR图谱, 可以看出涂层为浴轮层 状氮化嗍 $(t-\mathrm{BN})^{[23]}$. $t$-BN为 $h$-BN的三维无序结构, 其 中 $\mathrm{B}_{3} \mathrm{~N}_{3}$ 六圆环面内二维有序排列, $\mathrm{B}_{3} \mathrm{~N}_{3}$ 六圆环之间大

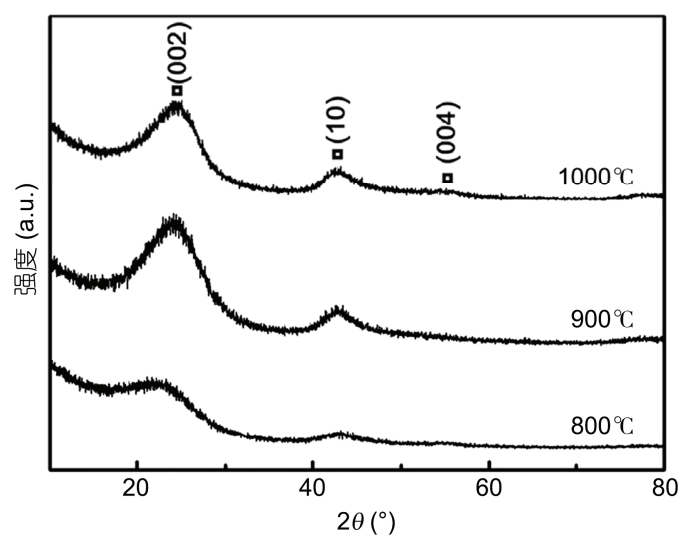

图 $5800 \sim 1000^{\circ} \mathrm{C}$ 沉积的BN涂层GIAXRD谱图

Figure 5 GIAXRD spectra of the coatings deposited at $800-1000^{\circ} \mathrm{C}$
致平行, 可沿 $c$ 轴旋转和位移 ${ }^{[24]}$. 随着沉积温度的上 升, (002)衍射峰收窄并且向右移动, 并且 $42^{\circ}$ 处的峰 也随之明显、收窄，说明所制备BN涂层的结晶性随 着沉积温度升高而趋于显著.

通过FTIR 和 GIAXRD表征的结果，可以看到在 较低的沉积温度 $\left(800 \sim 1000^{\circ} \mathrm{C}\right)$ 下, 以硼氨烷络合物为 前驱体，能够在纤维表面获得成分单一的 $\mathrm{BN}$, 而所 获得的BN涂层具有较适于作为界面的结构, 即介于 非晶和 $h$-BN之间的 $t$-BN. 相比于文献[25]所报道的 以嗍呋嗪为前驱体在 $800^{\circ} \mathrm{C}$ 气相沉积会出现 $\mathrm{N}-\mathrm{H}$ 吸收 峰，以及嗍酸尿素法 $1000{ }^{\circ} \mathrm{C}$ 以下会有大量的 $\mathrm{O}-\mathrm{H}$

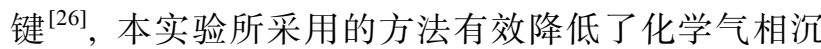
积温度, 且在较低温度下能够获得组分相对单一的 $\mathrm{BN}$ 涂层; 随着温度的升高, $\mathrm{B}-\mathrm{N}$ 的微观结构更加理 想. 鉴于本方法的目的在于获得复合材料的理想界 面层, 因此降低化学气相沉积的温度对提高纤维的 强度保留率具有十分重要的意义. 与目前通用的以 化学气相沉积制备BN涂层的方法相比 ${ }^{[27]}$, 本方法将 气相沉积反应的温度降低了至少 $100^{\circ} \mathrm{C}$; 与之前报道 的某些方法相比 ${ }^{[4,28]}$, 反应温度甚至降低了 $500{ }^{\circ} \mathrm{C}$. 对于陶瓷纤维包括石英纤维而言, 这将会有效地降 低沉积过程中长时间高温反应所带来的力学性能大 幅度下降的问题，提高复合材料的力学性能.

\section{4 涂层对碳化硅纤维力学性能的影响}

为了考察涂层厚度对纤维力学性能的影响, 本 文对有无沉积BN涂层的碳化硅纤维进行了单丝拉伸 强度的测试和分析. 图6给出了 $900{ }^{\circ} \mathrm{C}$ 下进行气相沉 积所得到的不同 $\mathrm{BN}$ 涂层厚度的碳化硅纤维的拉伸强 度对比结果, 以空白碳化硅纤维的拉伸强度作为对 比. 从图中可以看出, 未沉积 $\mathrm{BN}$ 涂层的空白碳化硅 纤维的强度为 $1.842 \mathrm{GPa}$, 而沉积了厚度为 $0.28 \mu \mathrm{m}$ BN涂层的碳化硅纤维强度保留率92.7\%(1.707 GPa). 在该温度下, 随着沉积时间的延长, 涂层沉积厚度增 加, 涂层厚度为 0.51 和 $0.82 \mu \mathrm{m}$ 的碳化硅纤维所对应 的拉伸强度分别为 1.539 和 $1.432 \mathrm{GPa}$, 保留率分别为 $83.6 \%$ 和 $77.7 \%$.

上述分析中碳化硅纤维的强度随涂层厚度的增 加而有一定程度的下降, 可能是由以下两个原因造 成: (1) 所采用的碳化硅纤维含氧量较高, 主要由 $\mathrm{SiC}$ 微晶和无定型 $\mathrm{SiC}_{x} \mathrm{O}_{y}$ 组成, 热稳定性较差, 高温下其 拉伸强度随时间的延长会有所下降; (2) 由于 $\mathrm{BN}$ 涂 


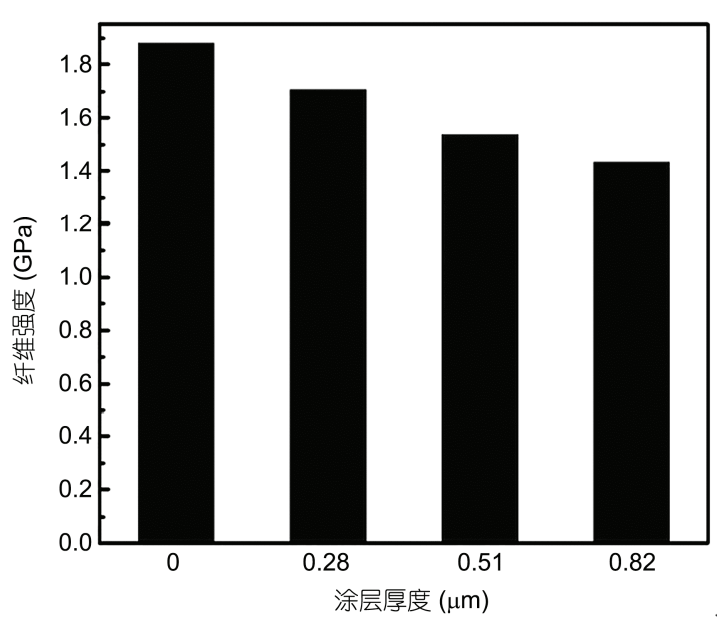

图 6 无BN涂层及不同涂层厚度的碳化硅纤维单丝拉伸强度对比 Figure 6 Tensile strength of silicon carbide fibers without or with different thickness of BN coating

层和碳化硅纤维之间热膨胀系数不匹配, 在降温过 程中BN涂层产生的热应力对纤维造成一定损伤, 导 致其强度下降, 而随涂层厚度增加其热失配现象越 显著, 这和文献报道的现象一致. 比如, Liu和Tian ${ }^{[26]}$ 在 $1000^{\circ} \mathrm{C}$ 用嗍酸-尿素法在碳化硅纤维表面制备 $\mathrm{BN}$
涂层, 纤维强度随厚度增加而下降, 涂层厚度为 0.4 $\mu \mathrm{m}$ 时, 碳化硅纤维强度保留率为 $60 \%$.

本方法制备的BN界面涂层厚度在不超过 $0.8 \mu \mathrm{m}$ 时, 其强度保留率达到 $80 \%$ 以上, 可满足陶瓷基复合 材料的制备对纤维力学性能的要求. 而若想获得力 学性能优异的复合材料, 建议 BN涂层厚度范围控制 在0.3 0.5 $\mu \mathrm{m}$ 范围内 ${ }^{[29]}$.

\section{3 结论}

本文以嗍氨烷络合物为前驱体, 采用低温化学 气相沉积法成功地制备了氮化嗍涂层, 并在碳化硅 纤维上得到了应用. 沉积温度在 $800^{\circ} \mathrm{C}$ 以上时, 可获 得成分单一的 $B N$, 且 $B, N$ 比例接近 $1: 1$. 随沉积温度 的升高其微观结构更加理想, 并且 BN涂层均一致密, 晶粒细小, 无孔洞裂纹等缺陷. 涂层厚度为 $0.28,0.51$ 和 $0.82 \mu \mathrm{m}$ 时碳化硅纤维强度保留率分别为 $92.7 \%$, $83.6 \%$ 和 $77.7 \%$. 该方法可以在较低温度下制备陶瓷 纤维的BN涂层，有效地降低长时间高温反应带来的 力学性能的下降, 进而提高其相应的复合材料的力 学性能.

\section{参考文献}

1 Ge L, Yang J, Qiu T. Study progress of preparation methods of hexagonal boron nitride (in Chinese). Electron Compon Mater, 2008, 27: 22-25 [葛雷，杨建，丘泰. 六方氮化硼的制备方法研究进展. 电子元件与材料, 2008, 27: 22-25]

2 Naslain R R. The design of the fibre-matrix interfacial zone in ceramic matrix composites. Compos Part A Appl S, 1998, 29: 1145-1155

3 Zhou W, Xiao P, Li Y, et al. Dielectric properties of BN modified carbon fibers by dip-coating. Ceram Int, 2013, 39: 6569-6576

4 Lorrette C, Weisbecker P, Jacques S, et al. Deposition and characterization of hex-BN coating on carbon fibers using tris(dimethylamino) borane precursor. J Eur Ceram Soc, 2007, 27: 2737-2743

5 Cheng Y, Yin X, Liu Y, et al. BN coatings prepared by low pressure chemical vapor deposition using boron trichloride-ammonia-hydrogenargon mixture gases. Surf Coat Technol, 2010, 204: 2797-2802

6 Geick R, Perry C H, Rupprecht G. Normal modes in hexagonal boron nitride. Phys Rev, 1966, 146: 543-547

7 Thomas J, Weston N E, O'Connor T E. Turbostratic boron nitride, thermal transformation to ordered-layer-lattice boron nitride. J Am Chem Soc, 1962, 84: 4619-4622

8 Udayakumar A, Ganesh A S, Raja S, et al. Effect of intermediate heat treatment on mechanical properties of $\mathrm{SiC}_{\mathrm{f}} / \mathrm{SiC}$ composites with BN interphase prepared by ICVI. J Eur Ceram Soc, 2011, 31: 1145-1153

9 More K L, Ailey K S, Lowden R A, et al. Evaluating the effect of oxygen content in BN interfacial coatings on the stability of SiC/BN/SiC composites. Compos Part A Appl S, 1999, 30: 463-470

10 Wen Z L, Xiao P, Li Z, et al. Microstructure and oxidation behavior of sol-gel mullite coating on SiC-coated carbon/carbon composites. J Eur Ceram Soc, 2015, 35: 3789-3796

11 Udayakumar A, Balasubramanian M, Gopala H B, et al. Influence of the type of interface on the tribological characteristics of ICVI generated $\mathrm{SiC}_{\mathrm{f}} / \mathrm{SiC}$ composites. Wear, 2011, 271: 859-865

12 Nyutu E K, Suib S L. Experimental design in the deposition of BN interface coatings on SiC fibers by chemical vapor deposition. Surf Coat Technol, 2006, 201: 2741-2748 
13 Rebillat F, Guette A, Brosse C R. Chemical and mechanical alterations of SiC nicalon fiber properties during the CVD/CVI process for boron nitride. Acta Mater, 1999, 47: 1685-1696

14 Adams A C. Characterization of films formed by pyrolysis of borazine. J Electrochem Soc, 1980, 128: 1378-1379

15 Müller F, Stöwe K, Sachdev H. Symmetry versus commensurability: epitaxial growth of hexagonal boron nitride on Pt(111) from B-trichloroborazine $(\mathrm{ClBNH})_{3}$. Chem Mater, 2005, 17: 3464-3467

16 Kim K K, Hsu A, Jia X, et al. Synthesis of monolayer hexagonal boron nitride on Cu foil using chemical vapor deposition. Nano Lett, 2012, 12: 161-166

17 Baitalow F, Baumann J, Wolf G, et al. Thermal decomposition of B-N-H compounds investigated by using combined thermoanalytical methods. Thermochim Acta, 2002, 391: 159-168

18 Baumann J, Baitalow F, Wolf G. Thermal decomposition of polymeric aminoborane $\left(\mathrm{H}_{2} \mathrm{BNH}_{2}\right)_{x}$ under hydrogen release. Thermochim Acta, 2005, 430: 9-14

19 Samuel F, Richard K, Carl M, et al. Pyrolytic decomposition of ammonia borane to boron nitride. Inorg Chem, 2010, 50: 783-792

20 Goubeau J, Ricker E. Borinhydrazin und seine pyrolyseprodukte. Z Anorg Allg Chem, 1961, 310: 123-142

21 Smith J, Seshadri K S, White D. Infrared spectra of matrix isolated $\mathrm{BH}_{3}: \mathrm{NH}_{3}, \mathrm{BD}_{3}: \mathrm{ND}_{3}$, and $\mathrm{BH}_{3}: \mathrm{ND}_{3}$. J Mol Spectrosc, 1971, 45: $327-337$

22 Wei Y S, Du Z J, Li X, et al. Formation and characterization of BN coating carbon fibers (in Chinese). J Funct Mater, 2014, B06: 76-78 [韦永山，杜作娟，李想，等. 碳纤维表面 BN 涂层的制备和表征. 功能材料, 2014, B06: 76-78]

23 Li J S, Zhang C R, Li B. Preparation and characterization of boron nitride coatings on carbon fibers from borazine by chemical vapor deposition. Appl Surf Sci, 2011, 257: 7752-7757

24 Li B, Zhang C R, Wang S Q, et al. Crystallization behaviors of carbon fiber reinforced $\mathrm{BN}-\mathrm{Si}_{3} \mathrm{~N}_{4}$ matrix composite. Cryst Res Technol, 2007, 42: 648-651

25 Li J S, Zhang C R, Li B, et al. Boron nitride coatings by chemical vapor deposition from borazine. Surf Coat Technol, 2011, 205: $3736-3741$

26 Liu H T, Tian H. Mechanical and microwave dielectric properties of $\mathrm{SiC}_{\mathrm{f}} / \mathrm{SiC}$ composites with $\mathrm{BN}$ interphase prepared by dip-coating process. J Eur Ceram Soc, 2012, 32: 2505-2512

27 Wu H, Chen M, Wei X, et al. Deposition of BN interphase coatings from B-trichloroborazine and its effects on the mechanical properties of SiC/SiC composites. Appl Surf Sci, 2010, 257: 1276-1281

28 Bansal N P, Chen Y L. Chemical, mechanical and microstructural characterization of low-oxygen containing silicon carbide fibers with ceramic coatings. J Mater Sci, 1998, 33: 5277-5289

29 Zhang L T, Cheng L F, Xu Y D. Interphase design of ceramic matrix composites (in Chinese). In: Proceedings of The 13rd National Conference on Composite Materials. 2004 [张立同, 成来飞, 徐永东. 陶瓷基复合材料的界面设计. 见: 第十三届全国复合材料学 术会议. 北京: 航空工业出版社, 2004] 


\title{
Preparation and characterization of boron nitride coating on silicon carbide fibers based on low-temperature chemical vapor deposition
}

\author{
WANG Chi, SUN NiJuan, ZHANG Juan \& ZHANG DaHai \\ Science and Technology of Advanced Functional Composite Laboratory, Aerospace Research Institute of Materials and Processing Technology, \\ Beijing 100076, China
}

Boron nitride $(\mathrm{BN})$ has been considered as promising material owing to its unique properties, such as high thermal stability, high chemical stability, high thermal conductivity and thermal shock resistance. Chemical vapor deposition (CVD) is the most popular method for the preparation of BN. However, the side-products (like $\mathrm{HF}, \mathrm{HCl}$ and $\mathrm{HBr}$ ) are corrosive and the crystallinity of $\mathrm{BN}$ is poor if the deposition temperature is $1300^{\circ} \mathrm{C}$. Herein we reported a new method for preparing $\mathrm{BN}$ by low-temperature CVD using ammonia borane as precursor on silicon carbide fibers. Ammonia borane was sublimated at $110-130^{\circ} \mathrm{C}$ using a heating belt, and the sublimated gaseous substance was transported to the deposition region where the silicon carbide fibers were placed at the deposition temperature of $900^{\circ} \mathrm{C}$. During the sublimation, a certain quality of ammonia borane was uniformly distributed in the quartz boat with a certain length, and the heating belt moved along the quartz tube with a fixed speed to the end of the boat. Thus the sublimation gas substances could be supplied continually and steadily. Scanning electronic microscopy (SEM), auger electron spectroscopy (AES), Fourier translation infrared spectroscopy (FTIR), and grazing incidence angle X-ray diffraction (GIAXRD) were used to characterize the properties of the coatings, and single fiber electron tensile machine was used to test the tensile strength of silicon carbide fibers without and with different thickness of coatings. The results illustrated that BN coating enwrapped well with the fibers with no defects like voids or cleavages. Meanwhile, the surface of the coating was uniform and dense. And the ratio of B and $\mathrm{N}$ was approximate 1: 1. Pure BN coating could be acquired at a relatively low deposition temperature, and microstructure of the $\mathrm{BN}$ coating was more ideal with the increasing of deposition temperature. Considering the balance between the coating crystallinity and strength retention of the fiber, $800-1000^{\circ} \mathrm{C}$ was the optimum deposition temperature range of BN coating on silicon carbide fibers. Compared with previous reports, this method reduced the preparation temperature effectively and could acquire pure BN on relatively low temperature. In this work, we aimed at preparing the ideal interphase of ceramic composite, and reducing the deposition temperature to elevate the fiber strength retention. This work could reduce the deposition temperature by at least $100^{\circ} \mathrm{C}$ and even $500^{\circ} \mathrm{C}$ compared with some cases. It would solve the reduction of mechanical properties during long time and high temperature deposition. At $900^{\circ} \mathrm{C}$, the strength retention of the fibers retained $92.7 \%, 83.6 \%$ and $77.7 \%$, as the coating thickness was $0.28,0.51$ and $0.82 \mu \mathrm{m}$, respectively. The strength retention of the silicon carbide fiber can meet the requirement of ceramic composite.

ammonia borane, chemical vapor deposition, silicon carbide fibers, BN coating

doi: 10.1360/N972016-00451 